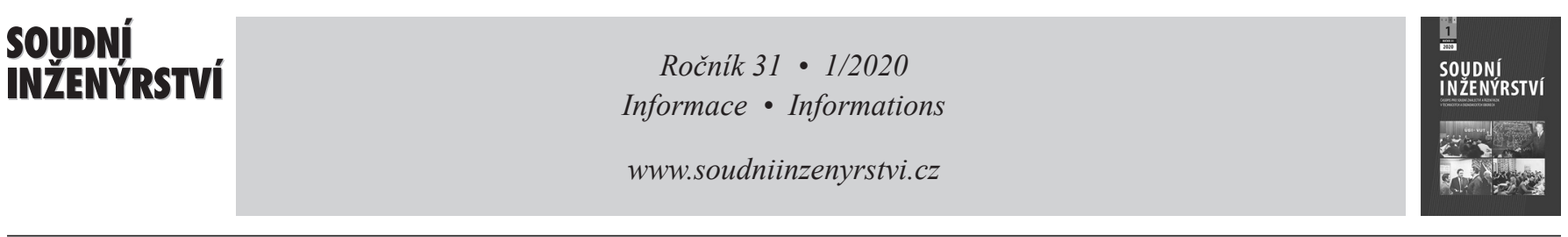

\title{
Mezinárodní konference soudního inženýrství ExFoS Brno 2020
}

\author{
International Scientific Conference of Forensic Engineering ExFoS Brno 2020
}

\author{
Michal Urbánek* , Barbora Schüllerová \\ Vysoké učeni technické v Brně, Ústav soudniho inženýrství
}

\begin{abstract}
Abstrakt
Ve dnech 23.-24. ledna 2020 se v prostorách Ústavu soudního inženýrství VUT v Brně konal již 29. ročník Mezinárodní vědecké konference soudního inženýrství (ExFoS 2020). Konference byla pořádána za podpory ÚSI VUT v Brně a AZO ČR a EVU ČR. Dvoudenní konference se zúčastnilo více než 200 tuzemských a zahraničních odborníkủ. Jako již tradičně byla, po úvodní společné části, konference rozdělena do tří sekcí, kterými jsou Analýza silničních nehod, oceňování motorových vozidel, strojů a zařízení, Stavebnictví a oceňování nemovitostí a Inženýrství rizik.
\end{abstract}

Klíčová slova: forenzní vědy, soudní inženýrství, znalec, rizikové inženýrství, konference.

\section{ÚVOD}

Ústav soudního inženýrství VUT v Brně se opět stal místem setkání odborníků v oblasti znalecké činnosti a inženýrství rizik. Již 29. ročník mezinárodní vědecké konference ExFoS 2020 se konal ve dnech 23.-24. ledna 2020. Konference byla podpořena Asociací znalců a odhadců ČR a Evropskou společností pro výzkum a analýzu nehod - Národní skupina ČR. Záštitu nad letošním ročníkem převzali rektor Vysokého učení technického v Brně prof. RNDr. Petr Štěpánek, CSc. dr. h. c. a Ministryně spravedlnosti České republiky Mgr. Marie Benešová. Konference byla pořádána k výročí 50 let ÚSI a při této události byl vydán Almanach 2020 ÚSI VUT v Brně, přičemž se během konference představily jednotlivé odbory ústavu včetně ukázek př́istrojového vybavení. O úspěchu konference svědčí nejen dlouholetá tradice jejího pořádání, ale i účast více než 200 odborníků z řad státní správy, vysokých škol, výzkumných a znaleckých ústavů a znalců z ČR i ze zahraničí. Účastníci si mohli vybrat z celkem 54 odborných přednášek.

V úvodním bloku konference byly řešeny aktuální otázky jako nový zákon o znalcích a připravované vyhlášky, nové

\begin{abstract}
On the $23^{\text {rd }}-24^{\text {th }}$ January 2020 was held the $29^{\text {th }}$ International Scientific Conference of Forensic Engineering (ExFoS 2020) at the Institute of Forensic Engineering, Brno University of Technology (IFE BUT). The conference was organized in co-operation with the AZO ČR and EVU ČR. The two days conference was attended by more than 200 Czech and foreign experts. As traditionally, after the joined part was the Conference divided into the three sections, which are Analysis of road accidents, the valuation of motor vehicles, machinery and equipment, Construction and real estate evaluation, Risk Engineering.
\end{abstract}

Keywords: forensic science, forensic engineering, expert, risk engineering, conference.

oceňovací standardy, znalecká činnost $\mathrm{v}$ oboru bezpečnosti práce a ve specializaci sebeobrana a použití zbraně. Následující jednání v samostatných sekcích umožnilo bohatou diskuzi na odborné platformě. Všechny přednášky byly přístupné i studentům doktorského a magisterských studijních programů ÚSI, kteří zde mohli nalézt inspiraci jak pro své diplomové či disertační práce, tak pro další vědecko-výzkumnou činnost.

Během prvního dne konference probíhala současně studentská konference JuFoS 2020 určená pro studenty doktorských i magisterských studijních programů. Prezentace studentských článků byla vedena formou posterové sekce doplněnou o diskuzi nad jednotlivými tématy. Součástí prvního dne konference byl i společenský večer v prostorách hotelu Prometheus, který umožnil neformální výměnu zkušeností mezi účastníky, navázání nových kontaktů a v neposlední řadě i přípravu budoucí spolupráce.

Následující přehled uvádí abstrakty vybraných př́spěvků prezentovaných na konferenci. Recenzovaný sborník s úplnými texty prŕspěvků je dostupný na webových stránkách konference www.exfos.cz. 


\section{SPOLEČNÁ SEKCE}

Vybrané rysy nových oceňovacích standardů vydaných v ČR Miloš Mařik

Institut oceňování majetku; katedra financí a oceňováni podniku, VŠE Praha

Cílem př́íspěvku je vymezit koncepci českých oceňovacích standardů. Nejprve je stručně charakterizována současná kvalita českého znaleckého oceňování, její problémy a z toho plynoucí potřeba Českých oceňovacích standardů. Dále jsou uvedeny základní rysy připravovaných standardů. Standardy budou mít tř́istupňovou strukturu. První stupeň tvoří etický kodex a obecné standardy pro všechny znalce. Jejich hlavním obsahem jsou zásady pro znalecké posudky (úplnost, důvodnost, odůvodněnost apod.). Druhý stupeň tvoří oceňovací standard, který obsahuje části společné pro oceňování všech druhů majetku, zejména definici bází hodnoty a další základní pojmy. Třetí stupeň pak budou tvořit speciální standardy pro oceňování jednotlivých typů majetku.

Nový zákon o znalcích, znaleckých kancelářích a znaleckých ústavech $\mathrm{z}$ pohledu znalecké praxe

Robert Kledus, Aleš Vémola, Albert Bradáč

Ústav soudního inženýrství, VUT v Brně

Článek se v souvislosti s novým zákonem o znalcích, znaleckých kancelárích a znaleckých ústavech zabývá třemi okruhy problémů, jež mohou ohrozit funkčnost systému, kterým má být od 1. ledna 2021 zajišt'ován řádný výkon znalecké činnosti v ČR. Jedná se o problémy související s povinností znalce vykonávat znaleckou činnost pouze v oboru, odvětví a případně specializaci, pro které je zapsán, s prokazováním kvalifikace u znaleckých kanceláří a znaleckých ústavů a s nevhodným stanovením závazných náležitostí znaleckého posudku. Článek analyzuje situaci, kterou lze důvodně očekávat v okamžiku, kdy nový zákon nabude účinnosti, a navrhuje i některá řešení, jež by mohla zabránit vážným problémů ve výkonu znalecké činnosti.

\section{Znalecké dokazování ve specializaci Sebeobrana a použití zbraně \\ Zdeněk Malánik ${ }^{a}$, Jiři Svoboda ${ }^{b}$, Martin Ficek $^{a}$, Michaela Mikuličováa Michal Gracla \\ ${ }^{a}$ Fakulta aplikované informatiky, UTB ve Zlině; bM2C Corporation Czech, a.s.}

V článku je pojednáno o problematice znaleckého dokazován se zaměřením na specializaci „Sebeobrana“ a „Použití zbraně“. Autor prezentuje zkušenosti s orgány činnými $\mathrm{v}$ trestním řízení z hlediska uvedené specializace, včetně forem a metod odborného dokazování. Důraz je kladen na analýzu nejčastěji pokládaných dotazů a uváděných názorů orgánů činných v trestním řízení směrem k uvedené problematice.

\section{SEKCE ANALÝZA SILNIČNÍCH NEHOD, OCEŇOVÁNÍ MOTOROVÝCH VOZIDEL, STROJŮ A ZAŘíZENÍ}

\section{Základ OBD elektromobilů Škoda a beznapět'ový stav po nehodě}

Michal Martinek, Martin Kudela

Škoda-Auto a. s.

Tento příspěvek pojednává o základním popisu v současné době nabízených elektromobilů značky Škoda-Auto, popisuje systém elektropohonu těchto vozů a jeho možnosti diagnostiky. Shrnuje diagnostikovatelné jednotky elektropohonu a možnosti prrístupu $\mathrm{k}$ datům $\mathrm{z}$ těchto jednotek prostřednictvím odborného servisu Škoda. Dále v př́spěvku je rozebrán beznapět'ový stav u elektrovozidla, popis a význam pilotní linie a vliv systému elektropohonu na stav vozu po nehodě a vliv na jeho diagnostiku.

\section{Soudní znalec a otázky spotřeby paliva vozidlových motorů}

Pavel Štěrba

TÜV SÜD Czech s.ro.

Příspěvek pojednává o požadavcích na měření spotřeby paliva silničních vozidel, formátech údajů a vlivu vnějších podmínek na její velikost. Upozorňuje na typická úskalí při jejím vyhodnocování.

Manipulace s tachografy, způsoby a jejich vliv na funkci elektronicky řízených systémů nákladních vozidel

Andrej Haring

Truck Consult, Liberec

Záznamové zařízení (digitální tachograf) je z legislativního hlediska povinnou součástí výbavy nákladních vozidel. Z technického hlediska lze systém digitálního tachografu chápat jako součást elektronické výbavy vozidla. Digitální tachograf je propojen s tachometrem a počítadlem ujeté vzdálenosti, a také s dalšími systémy vozidla. Propojení tachografů s dalšími systémy vozidla je realizováno prostřednictvím CAN (Controller Area Network), tedy přes vnitřní komunikační systém vozidla. Digitálním tachografem jsou přebírány některé signály z dalších elektronicky řízených systémů (EBS, motor, převodovka a další). Také elektronicky ř́zené systémy vozidla a komunikační obvody systémy přebírají z digitálního tachografu signály a informace pro svou činnost. Pokud dojde $\mathrm{k}$ nesprávné funkci digitálního tachografu, tak toto ovlivňuje správnou funkci těchto systémů vozidla. Tato problematika také přímo souvisí s manipulacemi s tachografy.

Odhad rychlosti protijedoucích vozidel, zejména motocyklů

Jan Unarski, Piotr Ciępka

Instytut Ekspertyz Sadowych, Kraków

Článek představuje výsledky výzkumu zabývajícího se odhadem rychlosti blížícího se vozidla. Zmíněny jsou teoretické vztahy, umožňující stanovit vzdálenost na kterou je možné provést odhad rychlosti blížicího se vozidla a teoretické výpočty porovnané $\mathrm{s}$ výsledky testů, ukazující na dobrou korelaci mezi oběma přístupy. Z provedené analýzy vyplývá, že řidiči čekající na př́ležitost překonat nebo se napojit na hlavní komunikaci z vedlejší komunikace mají často velké problémy odhadnout rychlost a vzdálenost vozidla blížícího se po hlavní silnici. Při daných podmínkách je snadné udělat chybu a střetnout se s rychle jedoucím vozidlem. 
Digitální tachografy - ověření rychlosti

Adam Reza $a^{a}$, Piotr Ciępka ${ }^{a}$, Robert Janczur ${ }^{b}$

${ }^{a}$ Instytut Ekspertyz Sądowych, Kraków, ${ }^{b}$ Politechnika Krakowska

Článek se zabývá porovnáním rychlostí jízdy vozidla zaznamenané za pomoci digitálního tachografu a rychlosti naměřené pomocí zařízení VBox.

Porovnání je prováděno při rychlosti od několika až do $70 \mathrm{~km} / \mathrm{h}$. Pro malé rychlosti bylo provedeno porovnání, jak pro jízdu vpřed, tak i vzad. Zkoušky obsahují zrychlování, jízdu ustálenou rychlostí i brzdění. Z porovnání vyplývá, že při malých rychlostech měří digitální tachografy rychlost s přesností do $1 \mathrm{~km} / \mathrm{h}$. Přri větších rychlostech, především během změn rychlosti jízdy, se odchylka rychlostí většinou pohybuje do $2 \mathrm{~km} / \mathrm{h}$.

\section{Výsledky nárazových zkoušek vozidla Toyota Yaris s EDR \\ Piotr Ciępka ${ }^{a}$, Jakub Zębala ${ }^{a}$,Adam Reza ${ }^{a}$, Wojciech Wach ${ }^{a}$, Michat Krzemiński ${ }^{b}$ ${ }^{a}$ Instytut Ekspertyz Sadowych, Kraków, ${ }^{b}$ Crash Data Poland}

Článek prezentuje výsledky validace dat zaznamenaných zapisovači údajů EDR vozu Toyota Yaris III, který byl podroben testům spočívajícím v nárazu pevné překážky rychlostí několika kilometrů za hodinu a čelní kolizi s jiným vozidlem rychlostí $50 \mathrm{~km} / \mathrm{h}$. Toto vozidlo bylo $\mathrm{z}$ výroby vybaveno zařízením $10 \mathrm{EDR}$, ale pro účely zkoušek byl navíc instalován zapisovač 12EDR. Data pro ověření hodnot zaznamenaných zapisovači pocházela z měřicího zařízení namontovaného uvnitř testovaného vozidla, které zahrnovalo senzory zrychlení a úhlové rychlosti. Získané výsledky ukazují velmi dobrou korelaci mezi skutečnou rychlostí a rychlostmi zaznamenanými zapisovači EDR - rozdíl mezi těmito rychlostmi během srážky nepřekročil $1 \mathrm{~km} / \mathrm{h}$.

Využití prostorových dat pro účely simulace nehodového děje Zdeněk Svatý, Tomáš Mičunek, Jakub Nováček

Ústav soudního znalectví v dopravě, FD, ČVUT v Praze

Soudně znalecká analýza je charakteristická omezenými či zcela chybějícími informacemi, které však mohou být zásadní pro správné vyhodnocení nehodového děje. Implementace nových měřičských postupů a technologií představuje jednu z možností jak problém s omezenými možnostmi řešit. Laserové skenování, více snímková fotogrammetrie, UAV snímkování či využití digitálních totálních stanic umožňují mnohem přesnější a detailnější dokumentaci místa nehody a tím také i rozšiřují možnosti znalců provádějících vlastní analýzu. Cílem tohoto příspěvku je ukázat možnosti jak s těmito daty pracovat, na co je možné je využít a na co je třeba si při jejich využití dát pozor. Na praktických př́kladech řešených $\mathrm{v}$ rámci znalecké činnosti jsou představeny možnosti tvorby detailních scén v rámci simulace a jejich možné následné využití se zohledněním aspektů znalecké činnosti a souvisejících omezení.

\section{Hranice využitel'nosti fotogrametrickej metódy pri dokumentovaní miesta dopravnej nehody Políciou \\ Stanislav Stehel ${ }^{a}, Z$ Zdeněk Svatýb, Peter Vertal'a, Ladislav Imrich ${ }^{a}$ \\ aÚstav znaleckého výskumu a vzdelávania, Žilinskej univerzity, ${ }^{b}$ Ústav soudního znalectvív dopravé, FD, ČVUT v Praze}

Článok sa zaoberá využívaním viacsnímkovej fotogrametrickej metódy pre potreby dokumentovania miesta dopravnej nehody Políciou počas znížených svetelných podmienok a nepriaznivého počasia. Žilinská univerzita v spolupráci s Políciou SR v súčasnosti realizuje výskum na zistenie využitia viacsnímkovej fotogrametrie za nepriaznivých svetelných a poveternostných podmienok. Blízka fotogrametria a jej následný výstup (3D model miesta dopravnej nehody) by mohol byt' v budúcnosti bohatým zdrojom informácií pre znalcov. Taktiež by sa mohol stat' neocenitel'ným dôkazom a podkladom pre sudcov, prokurátorov a advokátov pre reálnejšie zobrazenie situácie aká bola na mieste dopravnej nehody v čase obhliadky. Príspevok poskytuje súbor činností potrebných pre aplikáciu fotogrametrickej metódy dokumentovania miesta dopravnej nehody. Obrazová a priestorová rekonštrukcia je prezentovaná na 2 študijných prípadoch, ktoré boli vyhotovené počas noci a husteného sneženia. Pre každý výstup sú uvedené všeobecné postupy priestorovej rekonštrukcie a výsledné výstupy s ich praktickým využitím. Na záver sú zhrnuté limity a možnosti praktického využívania metódy viacsnímkovej fotogrametrie pre potreby Polície a znaleckého dokazovania.

\section{Nezistená chyba motorového vozidla pri pravidelnej kontrole na STK ako príčina vzniku dopravnej nehody}

Tomáš Korbel', Ladislav Imrich, Stanislav Stehel

Ústav znaleckého výskumu a vzdelávania, Žilinskej univerzity

V súčasnej dobe prichádza ku vzniku dopravných nehôd obvykle z dôvodu zlyhania l'udského faktora. V niektorých prípadoch však dochádza ku vzniku dopravnej nehody z dôvodu technickej závady vozidla, resp. jeho zlého technického stavu. Príspevok sa zaoberá prípadom reálnej cestnej dopravnej nehody nákladnej jazdnej súpravy, pri ktorej boli vykonanou forenznou analýzou technického stavu jazdnej súpravy zistené chyby, ktoré mali za následok vznik predmetnej dopravnej nehody. Zároveň príspevok poukazuje na potrebu dôsledného vykonávania kontrol technického stavu vozidiel na staniciach technickej kontroly.

\section{Testy z oblasti EDR - nehodových dat}

Michal Frydrýn, Luboš Nouzovský, Tomáš Mičunek, Zdeněk Svatý Ústav soudního znalectví v dopravě, FD, ČVUT v Praze

Příspěvek popisuje sérii crashtestů, při kterých bylo provedeno srovnání dat získaných ze systému EDR - Event Data Recorder a dat z nezávislého měřícího zařízení. Srovnání se zabývalo jak postřetovým zrychlením karoserie, tak i vyhodnocením předstřetového pohybu (např. zásah řidiče do řízení). Příspěvek prezentuje rozšířené možnosti analýzy nehod s pomocí získaných předstřetových dat o natočení volantu či rychlosti stáčení karoserie. Př́íspěvek dále popisuje aktuální novinky z pohledu legislativního zavedení systému EDR v Evropské unii.

\section{Vozidlo jako zbran̆}

Hana Chaloupkováa ${ }^{\text {, Libor Kopal }}{ }^{b}$

a Obvodni soud pro Prahu 5, bznalec, Mladá Boleslav

Příspěvek má za cíl na konkrétním př́ípadu prezentovat způsob rozhodování soudu o úmyslném trestném činu, kdy řidič osobního vozidla úmyslně najel do chodce jdoucího po chodníku. Základem pro rozhodování soudu byly především znalecké posudky z oboru doprava a zdravotnictví a výpověd' znalců $\mathrm{k}$ dané věci při hlavním líčení.

\section{Analýza příčného přemístění vozidla na mokrém povrchu}

Roman Mikulec

Ústav soudního inženýrství, VUT v Brně

Moderní vozidla jsou vlivem inovací v oblastech konstrukce pneumatik, vozidel (zejména podvozkových skupin) a asistenčních 
systémů schopna dosahovat stále vyšších jízdních limitů bez ztráty jízdní stability. Tato skutečnost se nejvíce projevuje při jízdě na povrchu se sníženou adhezí, s čímž se lze nejčastěji setkat v podobě mokrého povrchu vozovky. Tento článek se zabývá analýzou doby příčného přemístění vozidla při manévru příčného přemístění dvěma oblouky (vyhýbacího manévru) na mokrém povrchu vozovky. Pro testování bylo využito neparametrické jízdní dráhy, založené na normě ISO 3888-2, u které byla změněna jak př́ícná, tak podélná vzdálenost, o kterou se vozidlo přemístilo. Následně byla porovnána skutečná doba jízdního manévru s dobou, vypočtenou pomocí empirického vzorce (tzv. Kovaříkova vzorce).

\section{SEKCE STAVEBNICTVÍ A OCEŇOVÁNÍ NEMOVITOSTÍ}

\section{Oceňování pozemků pod vodními díly}

Jakub Hanák

Právnická fakulta, Masarykova univerzita

Př́spěvek se zabývá oceňováním pozemků s vodními díly. Nejprve vymezuje situace, kdy je nutné ocenit pozemek, na kterém se nachází vodní dílo. Poté analyzuje způsob určení ceny pozemku, na kterém se nachází vodní dílo ve vlastnictví cizího subjektu. Př́ispěvek se soustředí na určení obvyklé ceny pozemku.

\section{Náhradní metoda určení obvyklé ceny stavebních pozemků: určení obvyklé ceny stavebních pozemků metodou nepř́mého porovnání s využitím agregovaných údajů Českého statistického úřradu \\ Augustin Sadilek ${ }^{a}$, Filip Hakl ${ }^{b}$, Vlastimil Valac ${ }^{c}$ Eva Mačurováb \\ a'Ustav soudního inženýrství, VUT v Brně, ${ }^{b}$ Státní pozemkový úřad, ${ }^{c}$ Lesnická a dřevařská fakulta, MENDELU}

Autoři se v článku zabývají možnostmi určování obvyklé ceny stavebních pozemků metodou nepřímého porovnání s využitím agregovaných statistických údajů o průměrných kupních cenách stavebních pozemků.

\section{Historie, současnost a budoucnost oceńování lesa} v podmínkách ČR

Vlastimil Vala $a$, Jana Absolonováb ${ }^{b}$ Augustin Sadilek ${ }^{b}$, Filip Haklc $^{c}$ Eva Mačurovác ${ }^{a}$ Lesnická a dřevařská fakulta, MENDELU, ${ }^{b}$ Ústav soudního inženýrství, VUT $v$ Brně, 'Státni pozemkový úrad

Článek se zabývá historií, současností a budoucností oceňování lesa v podmínkách ČR. Historická analýza oceňovacích předpisů a oceňování na tržních principech od roku 1897 až po současnost je východiskem pro konkrétní návrhy úprav oceňovacích předpisů a tržního oceňování lesa. $\mathrm{V}$ rámci tržního oceňování je zmíněna problematika určování hodnoty lesa v podmínkách klimatických změn.

\section{Problematika místního šetření u nemovitostních portfolií většího rozsahu \\ Pavel Krchñák ${ }^{a}$, Petr Daňhel

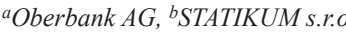

S rozvojem realitního a investorského trhu je stále frekventovanější situace, kdy je nutno ocenit velmi velké nemovitostní celky. Ty mnohdy svojí rozsáhlostí znemožňují v rámci místního šetření vidět všechny plochy, tak jako tomu je v př́ípadě standardních ocenění například rodinných domů či jednotlivých bytových jednotek. Je tedy potřeba vybrat reprezentativní vzorek, kde bude místní šetření realizováno. Jedním z prakticky používaných metodologických nástrojů je tzv. stratifikace portfolia. Př́ispěvek blíže představuje tento způsob výběru vzorků v prostředí oceňování nemovitostí a zasazuje jej do oceňovacího procesu.

\section{Plány rozvoje vodovodů a kanalizací (PRVK)}

Karel Plotěnýa, Michal Plotěnýb

${ }^{a} A S I O$ TECH, s r.o., ${ }^{b} A S I O N E W$, s.r.o.

V současnosti dosáhla Česká republika toho, že jsou v podstatě odkanalizovány větší aglomerace než 2000 EO, podle závazku při vstupu do EU má zajistit i u menších aglomerací odpovídající řešení odpadních vod. Vedle toho si dala i úkol dosažení dobrého stavu vod, což představuje mít vyřešený venkov jako celek, minimální odlehčení realizací HDV a mít pod kontrolou průmysl. Dalším omezením, je sociálně únosná cena vody. Všechny tyto tři závazky pak v podstatě znamenají rovnici o třech neznámých jejímž výsledkem by měl být plán jako jich dosáhnout. V České republice by měl představu konkretizovat tzv. Plán rozvoje vodovodů a kanalizací kraje (PRVK), který by měl vycházet z Plánů povodí a sociálních podmínek v př́slušné oblasti. Jako rozumný postup se jeví zpracování různých variant řešení odpadních vod a jejich vyhodnocení. Závěrem by měl být akt, kterým se občané obce rozhodnou o pro ně akceptovatelném řešení. Bohužel se tak neděje a výsledkem jsou často plány, které neakceptují zadávací podmínky, anebo postaví občany před hotovou věc. Př́spěvek se zabývá jevy ovlivňujícími rozhodování, které ve výsledku vedou $\mathrm{k}$ řešením nesplňujícím okrajové podmínky.

\section{Aktuální stav rekodifikace veřejného stavebního práva Alena Kliková \\ Právnická fakulta, Masarykova univerzita}

Př́íspěvek je věnován otázkám spojeným se změnami a legislativním vývojem právní úpravy veřejného stavebního práva, a to ve vztahu k praktickým dopadům těchto změn. Stavební zákon v posledních letech neustále prochází změnami, které mají vést ke zrychlení a zjednodušení jednotlivých procesů vedoucích $\mathrm{k}$ povolování staveb. V současné době probíhá rozsáhlá rekodifikace nejenom stavebního zákona, ale veřejného práva jako celku, včetně reorganizace veřejné správy. Př́spěvek bude zaměřen na současný stav rekodifikace, včetně vybraných plánovaných změn.

\section{Moderní metody používané při diagnostice mostů \\ Michal Jankì, Jiři Grošek}

Centrum dopravního výzkumu, v. v. $i$

Kvalitní dopravní infrastruktura je znakem dobře fungujícího národního hospodářství a potažmo vyspělosti celé společnosti. Za účelem zachování řádného stavu budov, mostů, silnic a dalších staveb je nezbytná jejich pravidelná údržba a kontrola skutečného stavu. Často platí, že pokud se podaří zachytit poruchu na počátku jejího vzniku, jsou náklady na její odstranění daleko nižší než po měsících až letech nekontrolované degradace. Lokalizovat poruchu včas, často znamená detekovat ji ještě dříve, než je viditelná pouhým okem. Klíčovým prostředkem ke zjištění skrytých defektů jsou metody nedestruktivního testování. V článku jsou popsány vybrané nedestruktivní metody, jež lze použít při diagnostice mostních objektů. 


\section{Zjištění prríčin poruch ocelových konstrukcí balkonů}

Leonard Hobst ${ }^{a}$, Petr Cikrle ${ }^{b}$

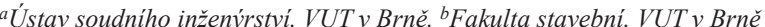

Pro rekonstrukce a dostavby stávajících železobetonových konstrukcí se s výhodou používají ocelové konstrukce. Při jejich návrhu je však nutno dodržovat přesné zásady, aby nedocházelo k následným poruchám. Pro odhalení případných vad a poruch se s výhodou dají použít některé metody nedestruktivního zkušebnictví.

Určování obvyklého nájemného za užívání stavebních pozemků metodou simulovaného nájemného pomocí agregovaných údajů Českého statistického úřadu

Filip Hakl ${ }^{a}$, Augustin Sadilek ${ }^{b}$, Vlastimil Vala ${ }^{c}$, Eva Mačurováa

${ }^{a}$ Státní pozemkový úřad, ${ }^{b}$ Ústav soudního inženýrství, VUT v Brně, 'Lesnická a dřevařská fakulta, MENDELU

Autoři se v článku zabývají možnostmi určování obvyklého nájemného stavebních pozemků metodou simulovaného nájemného s využitím agregovaných statistických údajů o průměrných kupních cenách stavebních pozemků.

\section{Stanovení zbytkové životnosti fóliových hydroizolačních materiálů}

Marek Novotný

Fakulta architektury. $\check{C} V U T$ v Praze

Vše má svojí životnost, včetně hydroizolací. Fóliové hydroizolace se vyznačují fenoménem „rychlé smrti“, což znamená, že dominantním signálem konce životnosti jsou masivní plošné zátoky. Hydroizolační fólie signalizují blížicí se konec své funkčnosti jinak vizuálně, ale zejména pak chemickými změnami ve své struktuře, které jsou relativně jednoduše identifikovatelné a lze z nich relativně jednoduše odhadnout/stanovit zbytkovou životnost.

\section{SEKCE INŽENÝRSTVÍ RIZIK}

\section{Environmentalne riziká hasiacich látok}

Karol Balog

Materiálovotechnologická fakulta STU so sídlom v Trnave

Požiare a ich likvidácia prinášajú nové aspekty z hl'adiska environmentálnej akceptovatel'nosti hasiacich látok a vykonávaných záchranných činností. Použité hasiace látky majú významný vplyv na likvidáciu požiarov, ale zároveň prinášajú environmentálne riziká. Tieto riziká predstavujú najmä znečistenie životného a obytného prostredia, porušovanie ozónovej vrstvy Zeme, skleníkový efekt, toxicitu použivaných hasiacich látok ako ajich životnost'.

\section{Enviromentální rizika, jejich podstata a možné dopady}

Jaroslav Rožnovsky

Zahradnická fakulta, MENDELU v Brnĕ

Počasí je stále dynamičtější, což se projevuje častějšími výskyty meteorologických a hydrologických extrémů, navíc s rostoucí intenzitou. Těmito projevy počasí se zvyšuje bezpečnostní riziko na našem území. Informaci o výskytu nebezpečných meteorologických a hydrologických prvků a jevů poskytuje Český hydrometeorologický ústav ve spolupráci s dalšími organizacemi formou Systému integrované výstražné služby. Podrobné rozpracování nebezpečí krizových situací, jejich příčin a postupy řešení uvádějí př́slušné typové plány.

\section{Lineární modely bezpečnosti - riziko a prevence}

Radim Roudný

Fakulta ekonomicko správní, UP v Olomouci

Pojednání obsahuje poznámky k možnosti požití jednoduchých lineárních modelů hodnocení rizika a prevence. Předpokládané riziko a prevence se týká chráněného aktiva, které hodnotíme v období před nežádoucí událostí a je hypotetické. Je zdůrazněno, že rozhodování má subjektivní charakter, může být pouze subjektivní, nebo subjektivně volíme podporu rozhodování. Bezpečnost vnímáme a popisujeme modely, které jsou zjednodušeným obrazem reality. Modely by měly být co nejjednodušší, ale dostatečně popisující jev o kterém rozhodujeme. Volbu typu modelu především ovlivňuje typ aktiva, hrozby, prostředí a musíme přihlédnout k tomu, kdo hodnocení provádí a pro koho je určeno. Reálné jevy jsou téměř vždy nelineární. V příspěvku je diskutována možnost použití lineárních modelů. Je uvedena kategorizace aktiv s charakterem jejich poškození a typů vnímání časové pravděpodobnosti. Předností lineárních modelů je jednoduchost a názornost. Pokud bezpečnost vyžaduje složitější modely, lineární modely mohou sloužit jako prvá fáze analýzy.

\section{Bezpečnost společnosti a krize}

Jaromir Novák

Fakulta tělesné kultury, UPv Olomouci

Dnešní společnost je pravděpodobně nejsložitější společností, která kdy na planetě existovala. Do jisté míry je relativně materiálně vyspělá, současně je však obtížně poznatelná a řiditelná, a tedy také krizová. Je také nerovnoměrná v mnoha oblastech fungování, což vede k rozporům ne vždy řešitelným. Současný svět proživá velice rychlé, prudké a rozsáhlé změny. Tyto jsou způsobeny jak vědomými, tak nevědomými aktivitami lidí - jednotlivců, kolektivů, regionů, států, nadnárodních struktur. Zjednodušeně řečeno strukturami mnohdy skryté moci. Svoji roli zde hrají i pohyby $\mathrm{v}$ př́rodě, způsobené jak samopohybem vývoje, tak i nechtěnými důsledky činnosti lidí. Tyto změny mají své kladné stránky, ale také přinášejí svá negativa i rizika a hrozby pro další vývoj. Potřeba bezpečnosti světa je stále naléhavější a žel také obtížněji uskutečnitelná.

\section{Lidský faktor a kultura bezpečnosti}

Dana Procházková

Fakulta dopravni, ČVUT v Praze

Detailní analýza havárií a selhání technických děl ukázala, že lidský faktor patří mezi jejich př́činy, a v některých př́ípadech je dokonce kořenovou příčinou. Proto je nutné v každém technickém díle dbát na kulturu bezpečnosti a pomocí ní systematicky realizovat program na zvyšování bezpečnosti.

\section{Přenos požadavků v kyber-fyzickém systému}

Jan Procházka, Dana Procházková Fakulta dopravni, ČVUT v Praze

S rozvojem automatizace, telemetrie a vzdáleného řízení roste význam komunikačních infrastruktur, skrze které jsou tyto technologie zajišstovány. Provoz systémů jako Chytrá města, 
Průmysl 4.0 nebo moderní infrastruktury je pak na kybernetické infrastruktuře kriticky závislý. Vzniká nám tak specifický př́klad systému systémů a to kyber-fyzický systém. Ten je význačný tím, že skrze vztahy mezi kybernetickým a fyzickým systémy jsou přenášeny i dopady selhání. Proto je nutné vyřešit i přenos a př́padné konflikty požadavků na zabezpečení a bezpečnost obou částí systému.

\section{Mimořádné události v drážní dopravě jako zdroj poznání rizik} Peter Hrmel

Fakulta bezpečnostniho inženýrství, VŠB TU Ostrava

Nedílnou součástí procesu posuzování rizik je identifikace rizik a př́ípadná tvorba scénářů nehodových dějů. To s ohledem na efektivitu celého procesu není jednoduché a je potřeba sestavit tým odborníků na danou problematiku. V oboru drážní dopravy je neocenitelným pomocníkem rozbor skutečně vzniklých mimořádných událostí. Za tímto účelem jsou stanovována opatření k zamezení opakování nehodových dějů s dopadem do pracovních činností zúčastněných profesí i do vnitropodnikových vzdělávacích aktivit. Př́spěvek se zaměřuje na vybrané závady v drážním provozu s poukazem na potřebnost přijímaných opatření. Mimořádné události v drážní dopravě rovněž představují neocenitelnou databázi scénářů skutečných pochybení a kroků, vedoucích k nežádoucím dopadům. Autor předkládá subjektivní pohled do předmětné oblasti z pozice pracovníka základního a operativního řízení železničního provozu.

\section{Minimalizace rizik při úchově potravin}

Pavel Valášek

Fakulta logistiky a krizového řizeni, UTB ve Zline

Potraviny s prodlouženou údržností mají při stravování obyvatelstva za mimořádných událostí a krizových situací své významné a nezastupitelné místo. Většinou se uplatňují následně po kompletovaných nouzových potravinových dávkách. Při výrobě takovýchto potravin se uplatňuje řada specifických fyzikálněchemických procesů, které v konečném důsledku rozhodují o jejich kvalitě a bezpečnosti pro konzumenta. Správné zvládnutí a kontrola technologických procesů jsou pak nezbytnými předpoklady úspěšného dosažení zamýšlených vlastností a užitné hodnoty takovýchto finálních produktů. $V$ př́ispěvku jsou rozebrány některé základní aspekty, které se na vlastnostech uvedených potravin podílí.

\section{Inženýrský př́ístup technického znalce $\mathbf{k}$ hodnocení střelných} poranění

Ludvik Juřiček

katedra managementu, Vysoká škola DTI, s.r.o.

Příspěvek se zabývá zvláštnostmi a hodnocením střelných poranění člověka malorážovým zbraňovým systémem, případně střepinou trríštivé munice. Metodologie vědeckého poznání zde vychází z morfologie skutečných projektilových poranění a lékařského hodnocení jejich klinické závažnosti. Současná soudnělékařská praxe ukazuje na postupné úzké propojení dvou doposud paralelních př́istupů $\mathrm{k}$ hodnocení střelných poranění, a to lékařského a technického (balistického). Vlastní kvantifikované hodnocení ranivého potenciálu malorážové střely (MRS) je pak v současnosti založeno na uplatnění základní hodnotící metody nepřímé identifikace, kdy je reálný cíl, při experimentálním postřelování, nahrazen substitučním fyzikálním modelem. Takto provedená balistická simulace je vhodným doplňkem jiných hodnotících metod, které využivají relativně široké spektrum použitelných analytických nebo experimentálně odvozených kritérií hodnocení ranivého potenciálu MRS (střepin). Poznatky získané z reálných střelných poranění mají v tomto systému stále své místo.

\section{Správná citace:}

URBÁNEK, M., SCHÜLlEROVÁ, B. Mezinárodní konference soudního inženýrství ExFos Brno 2020. Soudní inženýrství, 2020, 31(1), 48-53. DOI: http://dx.doi.org./10.13164/SI.2020.1.48. ISSN 1211-443X. 